\title{
THE ROLE OF GUT FLORA AND ANIMAL PASSAGE IN THE COLONISATION OF ADULT MICE WITH CAMPYLOBACTER JEJUNI
}

\author{
Leanne H. Field, Judy L. Underwood and L. J. Berry \\ Department of Microbiology, University of Texas, \\ Austin, Texas 78712-1095 USA
}

\begin{abstract}
SUmmary. Adult female mice were given drinking water containing tobramycin $0.05 \mathrm{mg} / \mathrm{ml}$ for a week. After a further day without antibiotic they were inoculated intragastrically with one of three strains of Campylobacter jejuni. Colonisation of the gastrointestinal tract was judged by culturing faecal pellets. Tobramycin-treated mice differed from untreated animals in that many more of them discharged infected pellets, and their pellets contained $5->300$ times more campylobacters. Colonisation could be prevented by inoculating the tobramycin-treated animals intragastrically, $24 \mathrm{~h}$ before the administration of $C$.jejuni, with a bacterial suspension prepared from normal faecal pellets. Coliforms, lactobacilli, the two in combination, and anaerobes grown from faecal pellets were not effective in preventing colonisation. Most of the $C$. jejuni were found in the large intestine of the tobramycin-fed mice. The persistence of colonisation of six dams nursing $C$. jejuni-infected offspring ranged from 10 to at least 29 weeks.
\end{abstract}

\section{INTRODUCTION}

Campylobacter enteritis is one of the more important causes of bacterial diarrhoea in man. It is produced by Campylobacter jejuni (Véron and Chatelain, 1973; Skerman, McGowan and Sneath, 1980), the organism designated C. fetus subsp. jejuni by Smibert $(1974,1978)$.

We reported previously the intestinal colonisation of infant mice, rats, hamsters and rabbits after intragastric infection with $C$. jejuni (Field et al., 1981b). The mice were all colonised for periods up to 2 weeks and infection was concentrated in the caecum and large intestine. Of five bacterial strains tested, only one caused an appreciable number of deaths $(13 \%)$. Weanling and young adult mice resisted colonisation.

The present paper is concerned with factors that influence colonisation of the gut of adult mice. The factors investigated were (a) disturbance of the intestinal flora by 
pretreatment with the antibiotic tobramycin, already used successfully by Turner $e t$ al. (1976) to produce colonisation of the intestine of mice with Candida albicans, and (b) the effect of subjecting $C$. jejuni to preliminary animal passage.

\section{MATERIALS AND METHODS}

Animals. Mice came from a breeding colony derived from $\mathrm{Crl}$ (CFW)(SW) BR Swiss Webster foundation stock (Charles River Farms, Wilmington, MA). Three were housed in each cage and they were given a pelleted diet and water ad libitum.

Organisms. Three strains of $C$. jejuni were used. Strain 517, a recent stool isolate from a patient with diarrhoea, was given to us by a local physician. The original isolation plate was taken to our laboratory where $C$. jejuni was transferred twice on plates of Brucella Agar (Difco Laboratories, Detroit, MI) plus 5\% sheep blood. The growth from the plates was suspended in Brucella Broth and 0.2-ml portions were frozen for subsequent use. Strain 517 was subsequently confirmed to be $C$. jejuni by the Texas State Department of Health. Strain ACl was isolated in Atlanta from a child with diarrhoea, and strain A2999 from an outbreak of campylobacter enteritis in Connecticut. Both were supplied by Mrs Joy Wells, Epidemiological Investigations Branch, Centers for Disease Control, Atlanta, GA. The subculture history of these strains is unknown. As with strain 517, they were subcultured twice and frozen after receipt in our laboratory.

Culture medium and growth conditions. Animals were inoculated with cells grown on Brucella Agar with defibrinated sheep blood 5\%. Brucella Agar with added antibiotics-a modification of a medium originally described by Blaser et al. (1978) - was used to grow C.jejuni from faecal pellets and from homogenised segments of the digestive tract. It contained cephalothin (Keflin, Eli Lilly Co., Indianapolis, MN) $12 \mu \mathrm{g} / \mathrm{ml}$, amphotericin B (E. R. Squibb and Sons, Princeton, NJ) $1.5 \mu \mathrm{g} / \mathrm{ml}$, trimethoprim (Sigma Chemical Co., St Louis, MO) 3.8 $\mu \mathrm{g} / \mathrm{ml}$, vancomycin (Sigma) $7.5 \mu \mathrm{g} / \mathrm{ml}$, and polymyxin B (Sigma) $1.9 \mathrm{IU} / \mathrm{ml}$. A microaerobic growth environment was produced by evacuating twice, to about $380 \mathrm{~mm} \mathrm{Hg}$, a modified stainless steel milk can and refilling it with a mixture of $\mathrm{N}_{2} 90 \%$ and $\mathrm{CO}_{2} 10 \%$. This gave a microaerobic atmosphere of about $5 \% \mathrm{O}_{2}$. Plates were incubated at $41 \mathrm{C}^{\circ}$ for $48-72 \mathrm{~h}$.

Preparation of inocula for intragastric infection. On receipt, strains of $C$. jejuni were subcultured twice on Brucella Agar with 5\% blood before being frozen in Brucella Broth (Difco) with glycerol $15 \%$ for use in subsequent experiments. For animal inoculation, a tube was removed from the deep freeze, inoculated on to Brucella-blood Agar, and incubated microaerobically for 24-48 h. One subculture was made and 24-h growth was suspended in Brucella Broth to a standard turbidity of 500 units as measured with a Klett-Summerson colorimeter (Klett Manufacturing Co., NY) fitted with a green filter. The number of colony-forming units $(\mathrm{cfu}) / \mathrm{ml}$ of inoculum was determined by plating dilutions in measured volumes on Brucella-blood Agar.

Inoculation of animals. Adult mice were inoculated intragastrically with $0 \cdot 1-\mathrm{ml}$ volumes of C. jejuni suspension by the oral-oesophageal method, with a $1-\mathrm{ml}$ tuberculin syringe and 23-gauge blunted needle tipped with polyethylene tubing. Infant mice weighing 2-3 g were inoculated intragastrically, as described by Field et al. (1981b).

Pretreatment of adult mice with tobramycin. For one week, mice were given drinking water that contained tobramycin $0.05 \mathrm{mg} / \mathrm{ml}$. This was then replaced by plain water and $24 \mathrm{~h}$ later the mice were infected. As adult mice drink c. $5 \mathrm{ml}$ of water/day (Dubos and Schaedler, 1961), each animal ingested c. $1.75 \mathrm{mg}$ of tobramycin.

Tests for colonisation. One week after infection, and where stated at further weekly intervals, a single fresh faecal pellet from each mouse was homogenised in $1 \mathrm{ml}$ of Brucella Broth by means of a glass test tube and teflon pestle. Ten-fold dilutions were inoculated on to Brucella-blood Agar containing antibiotics. After incubating the plates for $48 \mathrm{~h}$, colony counts were made. One and 2 weeks after infection, five mice were killed and from each the stomach, small intestine, caecum and colon were homogenised separately in $2 \mathrm{ml}$ of Brucella Broth; viable counts were then made as with the faecal pellets.

Prevention of colonisation. Two faecal pellets from each of five normal mice were homogenised in $5 \mathrm{ml}$ of saline. The suspension was then lightly centrifuged for $10 \mathrm{~min}$ at $c .1000 \mathrm{~g}$. 
Tobramycin-treated mice were inoculated intragastrically with $0.1 \mathrm{ml}$ of the supernate $24 \mathrm{~h}$ before being given $C$. jejuni by the same route.

The same procedure was performed with (a) a saline suspension of mouse faecal coliforms grown overnight on MacConkey's Agar (Difco), (b) a saline suspension of mouse faecal lactobacilli grown overnight on Rogosa SL Agar (Difco), (c) a mixture of equal parts of the coliform and lactobacillus suspensions, and (d) mouse faecal anaerobes cultured in cooked meat medium, subcultured twice in the same medium, and finally grown for $24 \mathrm{~h}$ in peptone yeast broth with glucose $1 \%$. Mice were inoculated with $0 \cdot 1 \mathrm{ml}$ of each suspension. The first three $(\mathrm{a}-\mathrm{c})$ were standardised at $500 \mathrm{Klett}$ units $\left(1-3 \times 10^{9} \mathrm{cfu} / \mathrm{ml}\right)$; the anaerobes were administered without standardisation or further characterisation.

Colonisation of dams nursing infected infant mice. Because Field et al. $(1981 \mathrm{~b})$ showed that some dams nursing infant mice that had been infected intragastrically with $C$. jejuni passed soft faeces containing blood and mucus, the faeces of a number of such animals was cultured at weekly intervals. The culture technique was as described above. Offspring were separated from dams at the time of weaning ( 3 weeks of age) and the mothers were housed singly thereafter.

Statistical treatment of data. Means and standard errors of the means were calculated for all data and the significance of differences between means was determined by the " $t$ " test.

\section{RESULTS}

\section{Colonisation of the digestive tract after tobramycin treatment}

The details and results of experiments with three strains of $C$. jejuni are shown in table I. Pretreatment with tobramycin increased the number of adult mice found colonised 1 and 2 weeks after infection, and also the degree of colonisation. Faecal pellets from 30 uninfected adult mice gave negative results on culture for $C$. jejuni. The mice were, therefore, not carriers of $C$. jejuni.

\section{Prevention of colonisation of tobramycin-treated mice by intragastric inoculation of faecal preparations}

In experiments with each of two strains of $C$. jejuni, the increased susceptibility to colonisation shown by tobramycin-treated mice was abolished by restoring the normal faecal flora (table II).

TABLE I

Effect of tobramycin on colonisation of the digestive tract of adult mice by three strains of $C$. jejuni

\begin{tabular}{|c|c|c|c|c|c|c|c|c|}
\hline \multirow{4}{*}{$\begin{array}{l}\begin{array}{c}\text { Strain } \\
\text { of } \\
\text { C. jejuni }\end{array} \\
517\end{array}$} & \multirow{4}{*}{$\begin{array}{c}\begin{array}{c}\text { Dose } \\
(\mathrm{cfu})\end{array} \\
1.8 \times 10^{8}\end{array}$} & \multirow{4}{*}{$\frac{\begin{array}{c}\text { Test } \\
\text { group }\end{array}}{\left\{\begin{array}{c}\text { Control } \\
\text { Tobramycin }\end{array}\right.}$} & \multicolumn{6}{|c|}{ Bacteriological findings } \\
\hline & & & \multicolumn{3}{|c|}{1 week after inoculation } & \multicolumn{3}{|c|}{2 weeks after inoculation } \\
\hline & & & \multirow{2}{*}{$\begin{array}{c}\begin{array}{c}\text { Average count } \\
\text { (cfu/pellet) } \pm S E\end{array} \\
14 \pm 8 \\
4300 \pm 1300\end{array}$} & \multicolumn{2}{|c|}{$\begin{array}{l}\text { Number of mice } \\
\text { positive total }(\%)\end{array}$} & \multirow{2}{*}{$\begin{array}{c}\begin{array}{c}\text { Average count } \\
\text { (cfu/pellet) } \pm \mathrm{SE}\end{array} \\
0 \\
350 \pm 170\end{array}$} & \multicolumn{2}{|c|}{ 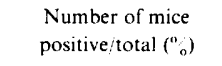 } \\
\hline & & & & $\left.\begin{array}{c}4 / 43(9) \\
35 / 43(81)\end{array}\right\}$ & $P=0.0005$ & & $\left.\begin{array}{c}0 / 25(0) \\
13 / 30(43)\end{array}\right\}$ & $\mathrm{P}<0.025$ \\
\hline A2999 & $4.5 \times 10^{8}$ & $\left\{\begin{array}{r}\text { Control } \\
\text { Tobramycin }\end{array}\right.$ & $\begin{array}{l}170 \pm 70 \\
860 \pm 300\end{array}$ & $\left.\begin{array}{l}14 / 25(56) \\
18 / 20(90)\end{array}\right\}$ & $P=0.005$ & $\begin{array}{r}60 \pm 30 \\
250 \pm 95\end{array}$ & $\left.\begin{array}{l}1025(40) \\
1324(54)\end{array}\right\}$ & $P=0.005$ \\
\hline $\mathrm{ACl}$ & $1.2 \times 10^{9}$ & $\left\{\begin{array}{r}\text { Control } \\
\text { Tobramycin }\end{array}\right.$ & $\begin{array}{c}60 \pm 40 \\
6000 \pm 2900\end{array}$ & $\left.\begin{array}{r}6 / 28(21) \\
23 / 30(77)\end{array}\right\}$ & $\mathrm{P}<0.0005$ & $\begin{array}{c}70 \pm 40 \\
970 \pm 450\end{array}$ & $\left.\begin{array}{r}5 / 28(18) \\
13 / 29(45)\end{array}\right\}$ & $\mathrm{P}=0.025$ \\
\hline
\end{tabular}


TABLE II

Effect of administration of normal faecal flora to tobramycin-treated adult mice on colonisation of the digestive tract with $C$. jejuni

\begin{tabular}{|c|c|c|c|c|}
\hline \multirow[b]{2}{*}{$\begin{array}{l}\text { Strain of } \\
\text { C. jejuni }\end{array}$} & \multirow[b]{2}{*}{$\begin{array}{l}\text { Dose } \\
\text { (cfu) }\end{array}$} & \multirow[b]{2}{*}{ Test group } & \multicolumn{2}{|c|}{$\begin{array}{l}\text { Presence of } C \text {. jejuni } 1 \text { week } \\
\text { after inoculation }\end{array}$} \\
\hline & & & $\begin{array}{l}\text { Average count } \\
\text { (cfu/pellet) } \pm S E\end{array}$ & $\begin{array}{l}\text { Number of mice } \\
\text { positive/total }(\%)\end{array}$ \\
\hline 517 & $3.2 \times 10^{8}$ & $\left\{\begin{array}{c}\text { Control } \\
\text { Tobramycin treated } \\
\text { Tobramycin treated } \\
+ \text { faecal suspension }\end{array}\right.$ & $\begin{array}{r}18 \pm 16^{*} \\
2760 \pm 810 \\
9 \pm 7^{*}\end{array}$ & $\left.\begin{array}{r}2 / 17(12) \\
13 / 16(81) \\
2 / 17(12)\end{array}\right\} P<0.005$ \\
\hline A2999 & $6 \cdot 1 \times 10^{7}$ & $\left\{\begin{array}{c}\text { Control } \\
\text { Tobramycin treated } \\
\text { Tobramycin treated } \\
+ \text { faecal suspension }\end{array}\right.$ & $\begin{array}{c}8 \pm 6 \dagger \\
1590 \pm 860 \\
170 \pm 150 \dagger\end{array}$ & 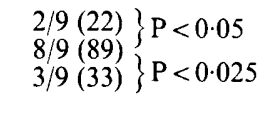 \\
\hline
\end{tabular}

* and + Differences not statistically significant.

\section{TABLE III}

Failure of selected indigenous intestinal bacteria to affect colonisation of the digestive tract of tobramycin-treated adult mice with $C$. jejuni

\begin{tabular}{|c|c|c|c|c|}
\hline \multirow{2}{*}{\multicolumn{2}{|c|}{ Test group }} & \multicolumn{3}{|c|}{$\begin{array}{l}\text { Presence of } C \text {. jejuni } 1 \text { week } \\
\text { after inoculation* }\end{array}$} \\
\hline & & $\begin{array}{l}\text { Average count } \\
\text { (cfu/pellet) } \pm S E\end{array}$ & $\begin{array}{l}\text { Numb } \\
\text { positiv }\end{array}$ & $\begin{array}{l}\text { er of mice } \\
\text { e/total }(\%)\end{array}$ \\
\hline \multicolumn{2}{|l|}{ Control } & $13 \pm 8$ & $1 / 21(5)$ & $\mathbf{P}<0.05$ \\
\hline $\begin{array}{l}\text { Tobramycin } \\
\text { treated }\end{array}$ & $+\left\{\begin{array}{l}\text { No added flora } \\
\text { Coliforms } \\
\text { Lactobacilli } \\
\text { Coliforms + lactobacilli } \\
\text { Anaerobes }\end{array}\right.$ & $\begin{array}{r}1680 \pm 970 \\
345 \pm 160 \\
380 \pm 190 \\
815 \pm 400 \\
542 \pm 313\end{array}$ & $\begin{array}{r}13 / 16(81) \\
15 / 17(88) \\
14 / 18(78) \\
9 / 17(53) \\
7 / 13(54)\end{array}$ & $\begin{array}{c}\text { No significant } \\
\text { effect }\end{array}$ \\
\hline
\end{tabular}

*Mice inoculated with $35 \times 10^{6} \mathrm{cfu}$ of strain 517 .

Failure of the intragastric inoculation of selected intestinal bacteria to prevent colonisation of tobramycin-treated mice with C. jejuni

Table III shows that neither coliforms, lactobacilli, coliforms and lactobacilli, nor anaerobes abolished the tobramycin-induced susceptibility of adult mice to $C$. jejuni.

Distribution of intragastrically administered $C$. jejuni in the digestive tract of control and tobramycin-treated adult mice

As with normal infant mice (Field et al., 1981b), C. jejuni infection was concentrated in the caecum and, more especially, the colon of adult mice pretreated with tobramycin and inoculated intragastrically (table IV). 


\section{TABLE IV}

Distribution of intragastrically administered $C$. jejuni in the digestive tract of control and tobramycin-pretreated adult mice

\begin{tabular}{|c|c|c|c|c|}
\hline \multirow[b]{3}{*}{ Site } & \multicolumn{4}{|c|}{ Bacteriological findings } \\
\hline & \multicolumn{2}{|c|}{1 week after inoculation* } & \multicolumn{2}{|c|}{2 weeks after inoculation* } \\
\hline & $\begin{array}{l}\text { Average count } \\
(\mathrm{cfu} / \text { segment }) \pm \mathrm{SE}\end{array}$ & $\begin{array}{l}\text { Number of mice } \\
\text { positive/total }(\%)\end{array}$ & $\begin{array}{c}\text { Average count } \\
\text { (cfu/segment }) \pm S E\end{array}$ & $\begin{array}{l}\text { Number of mice } \\
\text { positive/total }(\%)\end{array}$ \\
\hline Stomach $\left\{\begin{array}{c}\text { Control } \\
\text { Tobramycin }\end{array}\right.$ & $\begin{array}{l}74 \pm 74 \\
21 \pm 16\end{array}$ & $\begin{array}{l}1 / 10(10) \\
2 / 11(18)\end{array}$ & $\begin{array}{c}321 \pm 319 \\
58 \pm 37\end{array}$ & $\begin{array}{l}1 / 5(20) \\
2 / 8(25)\end{array}$ \\
\hline $\begin{array}{l}\text { Small } \\
\text { intestine }\end{array}\left\{\begin{array}{c}\text { Control } \\
\text { Tobramycin }\end{array}\right.$ & $\begin{array}{l}188 \pm 120 \\
118 \pm 107\end{array}$ & $\begin{array}{l}1 / 10(10) \\
3 / 11(27)\end{array}$ & $\begin{array}{l}133 \pm 131 \\
418 \pm 339\end{array}$ & $\begin{array}{l}1 / 5(20) \\
4 / 8(50)\end{array}$ \\
\hline Caecum $\left\{\begin{array}{c}\text { Control } \\
\text { Tobramycin }\end{array}\right.$ & $\begin{array}{l}120 \pm 120 \\
278 \pm 200\end{array}$ & $\begin{array}{l}1 / 10(10) \\
4 / 11(36)\end{array}$ & $\begin{array}{l}3000 \pm 2999 \\
1576 \pm 1489\end{array}$ & $\begin{array}{l}1 / 5(20) \\
5 / 8(63)\end{array}$ \\
\hline Colon $\left\{\begin{array}{c}\text { Control } \\
\text { Tobramycin }\end{array}\right.$ & $\begin{array}{c}480 \pm 319 \\
3675 \pm 2289\end{array}$ & $\begin{array}{l}3 / 10(30) \\
7 / 11(64)\end{array}$ & $\begin{array}{l}1161 \pm 1159 \\
1517 \pm 1213\end{array}$ & $\begin{array}{l}1 / 5(20) \\
6 / 8(75)\end{array}$ \\
\hline
\end{tabular}

*Mice inoculated with $27 \times 10^{6} \mathrm{cfu}$ of strain A2999.

\section{Establishment of a carrier state in dams of artificially infected infant mice}

In our report of an earlier experiment (Field et al., 1981b), some dams of infected infant mice had soft faeces often containing mucus and blood. The faeces of six naturally infected dams from that experiment have since been cultured for $C$. jejuni at weekly intervals for 11 weeks, and again at 21 and 29 weeks. Table V shows that these six mice became long-term carriers.

TABLE V

Intestinal colonisation in dams of infant mice infected intragastrically with C. jejuni strain ACI

\begin{tabular}{lcc}
\hline & $\begin{array}{c}\text { Range (and mean) of } \\
\text { cfu (thousands)/faecal pellet } \\
\text { (weekly sampling) }\end{array}$ & $\begin{array}{c}\text { Period of excretion } \\
\text { (weeks) }\end{array}$ \\
Dam no. & $0 \cdot 5-31(6)$ & $1-\geqslant 29$ \\
1 & $0 \cdot 2-36(8)$ & $1-\geqslant 29$ \\
2 & $0 \cdot 3-10(3)$ & $1-\geqslant 29$ \\
3 & $0 \cdot 9-14(5)$ & $1-\geqslant 21$ \\
4 & $0 \cdot 03-16(2)$ & $1-10$ \\
5 & $0 \cdot 2-5(1)$ & $1-\geqslant 21$ \\
6 & & \\
\hline
\end{tabular}

C. jejuni was not present in faecal pellets taken from the six dams $24 \mathrm{~h}$ before the infant mice were infected.

Dams nursing uninfected offspring were inoculated intragastrically with $C$. jejuni cultured in vitro from (a) a culture of strain 517 used in the experiment described above, (b) a faecal pellet taken from an infected infant mouse, and (c) a faecal pellet taken from a carrier dam. In no instance did the dams become colonised as judged by cultures of the faecal pellets they discharged after 1 week. 


\section{Direct intragastric inoculation of weanlings with a faecal suspension derived from infected dams}

As a test of possible virulence enhancement through animal passage, 10 normal weanling mice were inoculated twice, at an interval of $48 \mathrm{~h}$, with a suspension of the soft faeces of a nursing dam infected by her own artificially infected offspring. The number of $C$. jejuni in each dose of faecal suspension was $1.3 \times 10^{5} \mathrm{cfu}$. At the end of a week, one mouse had died and eight of the nine remaining animals were discharging faecal pellets containing on average 1900 C. jejuni. After 2 weeks, the animals were no longer excreting culturable $C$. jejuni.

\section{Discussion}

The gastrointestinal microflora of mice changes from a juvenile to adult form at 3-4 weeks of age (Schaedler, Dubos and Costello, 1965; Savage, 1978). During the first week of life, lactobacilli and streptococci of Lancefield group $\mathrm{N}$ colonise the stomach epithelium and anaerobic spiral-shaped microbes the epithelium of the large bowel. At the end of the first week, facultative anaerobes such as coliforms and enterococci spread throughout the bowel and remain in large numbers through the third week. During the second week, fusiform and spiral-shaped anaerobes appear and the population of coliforms and enterococci declines. After weaning, a segmented filamentous microbe colonises the small bowel and Torulopsis spp. become established in the stomach.

Previous studies have demonstrated that infant ( $\leqslant 7$ days) but not adult mice are susceptible to a variety of intestinal pathogens including Vibrio cholerae (Ujiiye et al., 1968; Guentzel and Berry, 1975), Candida albicans (Field et al., 1981a), and C. jejuni (Field et al., 1981b). The rapid increase in microflora that begins to occur after 1 week may explain why older mice cannot be colonised with $C$. jejuni.

Our present studies have demonstrated that adult mice can be rendered susceptible to colonisation with $C$. jejuni by pretreatment with the antibiotic tobramycin. Tobramycin pretreated mice were colonised for periods of 2 weeks, at which time their normal microflora presumably became re-established. As with infant mice (Field et $a l ., 1981 b$ ), the preferred site of colonisation was the caecum and colon.

Our use of faecal pellets to determine whether colonisation occurred permitted repeated observations on animals. Because the passage of food through the digestive tract of mice takes only 2-3 h (Berry and Smythe, 1959), the slow-growing C. jejuni is unlikely to have multiplied much in the pellets.

The importance of the indigenous microflora in preventing colonisation of adult mice by $C$. jejuni was shown by our studies. Feeding a faecal suspension from normal adult mice to tobramycin-treated adult mice $24 \mathrm{~h}$ before inoculation with $C$. jejuni prevented colonisation. Similar results in hamsters were reported by Wilson, Silva and Fekety (1981) for the intestinal pathogen, Clostridium difficile.

Our results differ from those of Blaser et al. (1983) who used caesarian-sectionderived and barrier-reared mice and, with three strains of $C$. jejuni, produced colonisation in all the adult mice by the intragastric administration of $10^{8} \mathrm{cfu}$. Colonisation was undiminished after 2 months and the stomach and upper part of the small intestine contained the largest number of campylobacters. The absence of 
normal intestinal flora in their animals is likely to have been responsible for the colonisation they observed.

Our work suggests that animal passage enhances the virulence of $C$.jejuni. First, nursing dams of artificially infected offspring became colonised for periods exceeding 6 months even though similar animals nursing normal offspring were not colonised by intragastric challenge with $C$. jejuni grown in vitro. Second, a small intragastric inoculum of $C$. jejuni derived from the soft faeces of colonised nursing dams resulted in the colonisation of weanling mice-animals that were not colonised after the inoculation of cultured organisms. Third, the large number of normal faecal organisms that must have been present in the faecal suspensions failed to prevent colonisation of weanlings with $C$. jejuni. This strongly suggests that there was enhanced virulence of the animal-passaged $C$. jejuni. It is conceivable that the infected infant mice discharged some blood and mucus in their stools that protected the $C$. jejuni against the dam's gastric acidity. Nevertheless, the in-vitro culture of microorganisms may result in a loss of surface structures essential for virulence (Costerton, Irvin and Cheng, 1981).

This work was supported in part by Public Health Service research grant AI-10466 from the National Institute of Allergy and Infectious Diseases.

\section{REFERENCES}

Berry L J, Smythe D S 1959 Effects of bacterial endotoxin on metabolism. II. Protein-carbohydrate balance following cortisone. Inhibition of intestinal absorption and adrenal response to ACTH. Journal of Experimental Medicine 110:407-418.

Blaser M, Cravens J, Powers B W, Wang W L 1978 Campylobacter enteritis associated with canine infection. Lancet 2:979-981.

Blaser M J, Duncan D J, Warren G H, Wang W L 1983 Experimental Campylobacter jejuni infection of adult mice. Infection and Immunity 39:908-916.

Costerton J W, Irvin R T, Cheng K-J 1981 The role of bacterial surface structures in pathogenesis. CRC Critical Reviews in Microbiology 8:303-338.

Dubos R J, Schaedler R W 1961 The effect of bacterial endotoxins on the water intake and body weight of mice. Journal of Experimental Medicine 113:921-934.

Field L H, Pope L M, Cole G T, Guentzel M N, Berry L J 1981a Persistence and spread of Candida albicans after intragastric inoculation of infant mice. Infection and Immunity 31:783-791.

Field L H, Underwood J L, Pope L M, Berry L J 1981b Intestinal colonization of neonatal animals by Campylobacter fetus subsp. jejuni. Infection and Immunity 33:884-892.

Guentzel M H, Berry L J 1975 Motility as a virulence factor for Vibrio cholerae. Infection and Immunity 11:890-897.

Savage D C 1978 Factors involved in colonization of the gut epithelial surface. American Journal of Clinical Nutrition 31:S131-S135.

Schaedler R W, Dubos R, Costello R 1965 The development of the bacterial flora in the gastrointestinal tract of mice. Journal of Experimental Medicine 122:59-66.

Skerman V B D, McGowan V, Sneath P H A 1980 Approved lists of bacterial names. International Journal of Systematic Bacteriology 30:225-420.

Smibert R M 1974 Campylobacter. In: Buchanan R E, Gibbons N E (eds) Bergey's Manual of Determinative Bacteriology, 8th edn. Williams and Wilkins, Baltimore, MD, pp 207-212.

Smibert R M 1978 The genus Campylobacter. Annual Review of Microbiology 32:673-709.

Turner J R, Butler T F, Johnson M E, Gordee R S 1976 Colonization of the intestinal tract of conventional mice with Candida albicans and treatment with antifungal agents. Antimicrobial Agents and Chemotherapy 9:787-792. 
Ujiiye A, Nakatomi M, Utsunomiya A, Mitsui K, Sogame S, Iwanaga M, Kobari K 1968 Experimental cholera in mice. I. First report on the oral infection. Tropical Medicine (Nettai Igaku) 10:65-71.

Véron M, Chatelain R 1973 Taxonomic study of the Genus Campylobacter Sebald and Véron and designation of the neotype strain for the type species, Campylobacter fetus (Smith and Taylor) Sebald and Véron. International Journal of Systemic Bacteriology 23:122-134.

Wilson K H, Silva J, Fekety F R 1981 Suppression of Clostridium difficile by normal hamster cecal flora and prevention of antibiotic-associated cecitis. Infection and Immunity $34: 626-628$. 